4. Compendium on Cyber Security of Election Technology. July 2018. URL: https://www.ria.ee/sites/default/files/content-editors/kuberturve/cyber_ security_of_election_technology.pdf?fbclid=IwAR2bptHm1_-OGOEYs9jcFHLbSPJaM6oJ4QxzrnzvqB7wBMjfyWtPjmfTBU (дата звернення: 16.09.2021)

5. Керівна настанова щодо виборів. Ухвалена Комітетом з питань Конвенції про кіберзлочинність (Т-CY) на 21-ому засіданні 8 липня 2019 року. URL: https://rm.coe.int/elections-digital-technologies-humanrights/ 16809fa91c (дата звернення: 16.09.2021)

DOI https://doi.org/10.30525/978-9934-26-147-3-4

\title{
ВПЛИВ ПОПУЛІЗМУ НА ДИНАМІКУ ЗМІН У ПУБЛІЧНОМУ СЕКТОРІ
}

\author{
Семенець-Орлова I. А. \\ доктор наук з державного управління, доцент, \\ завідувач кафедри публічного адміністрування \\ Міжрегіональної академії управління персоналом \\ м. Київ, Україна
}

Сучасний популізм $\epsilon$ результатом перетворення політики на маркетинг. Популістський світогляд простий: загалом світ поділяється на широкі групи порядних «простих людей» та корумповану «еліту». Таким чином, популіст підживлює свою політичну активність антиелітарними настроями, теоріями змови «людей при владі» та невдоволенням тенденцією глобалізації. Крім того, важливим компонентом популізму є недовіра людей до інших політиків та інституцій, навіть якщо ці інститути є демократичними.

Сьогодні світ має безліч причин для зростання популярності популістських настроїв. Він стає дедалі складнішим, традиційне політичне поле змінюється, і політичні партії все менше спираються на політичні переконання («ліві» чи «праві»). Окрім того, традиційні політичні партії із власною перевіреною десятиліттями інфраструктурою руйнуються. Вони втрачають осередки, активістів, ідеологію та джерела фінансування i, тим самим, звільняють простір для нових сил.

Звичайно, популіст репрезентує себе, насамперед, як представника «маленьких» чесних людей, інтереси яких недостатньо представлені. Крім того, він пропонує прості рішення складних проблем. Як зазначив історик Р. Хофстедтер, історичне значення феномену популізму поля16 
гає в тому, що це був перший масштабний політичний рух, який зобов'язував державу першочергово дбати про загальний добробут широких верств населення [2, с. 55]. Свропейський популізм - це феномен переважно правого ідеологічного спектру, що включає страх перед Іншими - мігрантами. Використовуючи ці гасла, крайні праві популісти пройшли в парламенти та виконавчі органи влади також у Швеції (2018 р.), Австрії, Італії (2010 р., 2019 р.), Данії. У варіанті крайніх лівих ідей популізм представлений у Венесуелі - у політиці лідерів Уго Чавеса та Ніколаса Мадуро. Однак, наразі саме приклад економічної кризи у Венесуелі $є$ переконливим аргументом для критики популізму.

Взагалі у XIX столітті слово «популізм» часто мало позитивне значення. Популізм був синонімом «популістських» демократичних рухів, які виступали за зміцнення політичних прав «простих людей». «Популярні партії» сучасної Свропи є певною мірою нащадками цього старого популізму. Це той аргумент, яким часто оперують сучасні популісти. Наприклад, один із головних ідеологів Д. Трампа (під час його кампанії) Стів Беннон наразі намагається об’єднати популістські рухи в Свропі. Однак, хоча традиційні «популісти» звертаються до людей як до уявної одиниці, сучасні «популісти» дивляться на окремих «звичайних людей» як на своїх виборців [1].

У болючій скруті люди вірять у диво чи просто чинять відчайдушно. Комбінація справді унікальна. Для України мрії про «долар по вісім»символ економічної кризи, зубожіння, стагнації. Закономірно актуалізується популістська риторика через загострення соціально-економічних проблем, коли відчайдушно віриться в диво. Незважаючи на відмінності між політиками в різних країнах, політик-популіст завжди говорить виборцям саме те, що вони хочуть почути. Він не схожий на класичного політика-переконувача, який керує своєю партією на основі певних ідей. Він більше схожий на сучасного маркетолога, який діє лише після ретельного «вимірювання» своєї аудиторії.

Наприклад, у сучасному світі багато країн мають проблеми у аспекті зростання нерівності між багатими та бідними. За підрахунками Forbes, кількість мільярдерів у світі за останні два десятиліття зросла в п’ять разів.

На сьогодні багатство 8 найбагатших людей на планеті дорівнює багатству найбідніших 3,5 мільярдів людей, або половини світового населення, $1 \%$ найбагатших людей володіють близько $40 \%$ багатства світового населення. I хоча багаті переважно виграють від глобалізації та їі «відкритості», найбідніші часто програють (тому що конкуренція на ринку праці зростає через мігрантів). Класичні «ліві» (соціалістичні) 
партії виступають за соціальну рівність та відкритість світу; «праві» (патріотичні) - за національну ідентичність та захист від викликів зовнішнього світу. Проблематика сучасного політичного простору охоплює ідейний спектр і лівих, і правих, а відповідь на ці проблеми лежить поза класичними ідеологічними системами. Рішення вимагають складних балансів, що не можливо за наявності у політиків простих відповідей на поточні комплексні проблеми. Тому в умовах недовіри до політичних думок виборці прагнуть звертати увагу на особистість політика, його здатність говорити простими гаслами та на його вміння давати обіцянки. Головне - не стільки його ідеї, скільки енергія та агресивність, 3 якими він атакує нинішню «систему». Зосередження уваги на особистостях, уособлення політики - це ще один крок до популізму.

У 2016 році Д. Трамп був зіркою популізму в західних країнах. Разом 3 тим проміжні вибори в США в листопаді 2018 року показали, що ситуація не $є$ безхмарною для республіканців. Вони програли вибори в Палату представників. Тому Трамп втратив деякий простір для маневру. Його рейтинг трохи знизився, але залишався високим. За рейтингами різних відомств, у 2019 р. 52\% американців не підтримували політику президента і $42 \%$ підтримували. Порівняно з різким падінням рейтингу Е. Макрона у Франції чи деяких інших лідерів демократичних країн це можна вважати успіхом. I це ще одна загадка популістів: незважаючи на надмірну простоту деяких їхніх ідей, сьогодні вони здатні не лише здобути владу, але й зберегти іiі.

Якщо класичні демократи швидко розчаровуються прагненням до рівноваги в складних системах, популісти знають, як утримати справжній електорат. У сучасному світі розділених груп простір для раціональної політики зменшується: не можна перемогти, вирішуючи проблеми всіх. Можна перемогти, коли знаєш, як переконати тих, хто тобі віритиме. 2017 та 2018 роки у світі були роками усвідомлення того, що наслідки простих рішень можуть бути дуже складними. Більше двох років після доленосного голосування за вихід із Свропейського Союзу (ЄC) британці вирішуватимуть, як і за яких умов вони вийдуть з ЄС. Депутати в Палаті представників відмовились голосувати за угоду Великобританії з $Є С$, яку підтримувала прем'єр-міністр Тереза Мей. Популістські заклики вийти з СС обіцяли вирішити всі проблеми Великобританії-з мігрантами, з фінансами та із законодавством, визначеним Брюсселем. Компромісне рішення Т. Мей критикувалося з усіх боків як недостатньо сильне, зазначалося, що Великобританія стане колонією Брюсселя. Інші аргументи включали підозри, що Великобританія втратить європейський ринок. 
На сьогодні Україна є демократичною державою, але 3 авторитарними пережитками, які не дозволяють повноцінно розвиватися. Українське суспільство рухається шляхом, який означає не лише побудову демократичної політичної системи, але й кардинальне переосмислення будь-якого попереднього політичного та соціальноекономічного розвитку. За цих умов, одним із завдань постає повна оцінка процесу демократизації в Україні, перебігу внутрішніх перехідних процесів іiї політичної системи, а також перспективи формування ліберальної демократії. Окрім проголошеного Конституцією України курсу на розбудову демократичної правової держави та громадянського суспільства, на політичний процес в Україні суттєво впливають внутрішні історичні чинники та специфічні моделі розвитку соціального організму, які іноді не збігаються із загальнодержавним нормативним курсом.

\section{Література:}

1. Barndt, W. (2019). Populism in America: Christopher Lasch, bell hooks, and the Persistence of Democratic Possibility. Journal of Politics and Society. Vol. 31. Is. 3-4. P. 278-299, https://doi.org/10.1080/08913811.2019.1713632.

2. Hofstadter, R. (1995). The Age of Reform. From Bryanto FDR. New York. 61 p. 